\title{
Transforming growth factor beta receptor II (TGFBR2) promoter region polymorphism
}

\author{
Sora Yasri ${ }^{1}$ (1) $\cdot$ Viroj Wiwanitkit $^{2}$
}

Received: 12 August 2019 / Accepted: 19 August 2019 / Published online: 26 August 2019

○) Springer Science+Business Media, LLC, part of Springer Nature 2019

To the Editor,

We read the publication on "Transforming growth factor beta (TGF $\beta$ ) receptor II (TGFBR2) promoter region polymorphism in Brazilian breast cancer (BC) patients: association with susceptibility, clinicopathological features, and interaction with TGFB1 haplotypes." with a great interest [1]. Vitiello et al. concluded that $G-875 A$ is a protective factor against $B C$, especially from luminal-A subtype, but may promote anaplasia in established tumors, consistent with $T G F \beta$ signaling roles in $B C$ [1]. Indeed, the effect of genetic factor on BC is possible. The identified effect of G-875A might be modified by other genetic and non-genetic factor; therefore, the confounding effect of TGF $\beta 1$ can be expected. Nevertheless, the isolated effect of G-875A polymorphism might be explainable via molecular change analysis. Based on the quantum molecular calculation technique as presented in the previous reports [2-4], the molecular weight change due to G-875A polymorphism is equal to $-16 \mathrm{~g} / \mathrm{Mol}$ (151.13 g/Mol to $135.13 \mathrm{~g} / \mathrm{Mol})$. Similar to the described pathogenesis in other medical disorders [2-4], the G-875A variant will result in a less expression of TGFBR2, which further imply a less amount of growth factor to stimulating BC carcinogenesis. This result is concordant with the previous report by Barlow et al. that a higher expression of TGFBR2 is associated with a poorer prognosis of breast tumor [5].

This comment refers to the article available at https://doi. org/10.1007/s10549-019-05370-1.

\footnotetext{
Sora Yasri

sorayasri@outlook.co.th

KMT Primary Care Center, Bangkok, Thailand

2 Dr DY Patil University, Pune, India
}

Funding None

\section{Compliance with Ethical Standards}

Conflict of interest The authors declare that they have no conflicts of interest.

Ethical approval This article does not contain any studies with human participants performed by any of the authors.

Informed consent This article does not contain any studies with human participants performed by any of the authors and requires no informed consent provision.

\section{References}

1. Vitiello GAF, Amarante MK, Banin-Hirata BK, Campos CZ, de Oliveira KB, Losi-Guembarovski R, Watanabe MAE (2019) Transforming growth factor beta receptor II (TGFBR2) promoter region polymorphism in Brazilian breast cancer patients: association with susceptibility, clinicopathological features, and interaction with TGFB1 haplotypes. Breast Cancer Res Treat 1:1. https ://doi.org/10.1007/s10549-019-05370-1

2. Joob B, Wiwanitkit V (2018) Interleukin-2-330T/G and interleukin-10-1082A/G genetic polymorphisms and B-cell non-hodgkin lymphoma. Turk J Haematol 35(4):301-302

3. Yasri S, Wiwanitkit V, Joob B (2017) WWOX rs11644322 polymorphism, gemcitabine, and pancreatic cancer. Indian J Med Paediatr Oncol 38(3):409-410

4. Srriwijitalai W, Wiwanitkit V (2018) Interleukin-6-174G/C polymorphism and end-stage renal disease: is there any role? Saudi J Kidney Dis Transpl 29(3):747-748

5. Barlow J, Yandell D, Weaver D, Casey T, Plaut K (2003) Higher stromal expression of transforming growth factor-beta type II receptors is associated with poorer prognosis breast tumors. Breast Cancer Res Treat 79(2):149-159

Publisher's Note Springer Nature remains neutral with regard to jurisdictional claims in published maps and institutional affiliations. 